\title{
Synthesis of $\mathrm{CdIn}_{2} \mathrm{~S}_{4}$ Microsphere and Its Photocatalytic Activity for Azo Dye Degradation
}

\author{
Jianhui Huang, ${ }^{1}$ Wei Lin, ${ }^{2}$ and Jianqin Chen ${ }^{1}$ \\ ${ }^{1}$ College of Environmental \& Biological Engineering, Putian University, Putian 35110, China \\ ${ }^{2}$ Department of General Surgery, Affiliated Hospital of Putian University, Putian 351100, China \\ Correspondence should be addressed to Jianhui Huang; owenhuang95@163.com
}

Received 20 February 2014; Accepted 20 March 2014; Published 30 March 2014

Academic Editors: J. Shi and H. Zhou

Copyright (c) 2014 Jianhui Huang et al. This is an open access article distributed under the Creative Commons Attribution License, which permits unrestricted use, distribution, and reproduction in any medium, provided the original work is properly cited.

\begin{abstract}
$\mathrm{CdIn}_{2} \mathrm{~S}_{4}$ was prepared by ultrasonic spray pyrolysis. The prepared $\mathrm{CdIn}_{2} \mathrm{~S}_{4}$ was characterized by X-ray diffraction (XRD), field emission scanning electron microscopy (FSEM), transmission electron microscopy (TEM), UV-visible diffuse reflectance spectroscopy (UV-Vis DRS), and $\mathrm{N}_{2}$-sorption techniques. Aqueous photocatalytic activity was evaluated by the decomposition of methyl orange under visible light irradiation. The results indicate that the prepared $\mathrm{CdIn}_{2} \mathrm{~S}_{4}$ has spherical morphology with mesoporous structure which can efficiently degrade methyl orange in water. The sample prepared at $500^{\circ} \mathrm{C}$ exhibits the optimized photocatalytic activity.
\end{abstract}

\section{Introduction}

Azo dyes, a large class of synthetic organic dyes that contain nitrogen as the azo group $-\mathrm{N}=\mathrm{N}-$ as part of their molecular structures. More than half the commercial dyes belong to this class which have been widely used in many industries such as the production of textiles, paint, ink, and cosmetics [1]. The effluent from azo dyes industries contains substantial amounts of such dyes and their breakdown products, which causes coloration of water and poses a threat to aquatic life [24], mutagenic/carcinogenic [5], and genotoxic [6]. Therefore dyes effluent poses a great threat to the environment and increasing attention has been paid to the treatment of dye effluent. While due to the complex aromatic structure and stability of these dyes, conventional biological treatment processes are ineffective for their degradation [7]. The absorption and coagulation processes are only able to absorb them up to some extent, but the sludge produced from both processes becomes more difficult to be disposal [8].

In the past several decades, semiconductor-mediated photocatalytic oxidation has been proved to be a promising technology for the treatment of water containing azo dyes [9]. Among a variety of semiconductor materials, the titanium dioxide $\left(\mathrm{TiO}_{2}\right)$ photocatalysts have been most extensively investigated and used because of their physical properties and economic advantages, such as high redox power, photostability, chemical inertness, and cheapness [10]. However, $\mathrm{TiO}_{2}$ can only absorb a very small ultraviolet part (3-4\%) of solar light because of its wide band gap (3.2 eV for anatase) which constrains the extensive applications of $\mathrm{TiO}_{2}$. Thus, considerable efforts have been devoted to develop new visible responded photocatalyst which is still a significant issue in both academic and practical applications.

Among various new photocatalysts, multinary chalcogenide semiconductors have attracted great attention because of the instability of the mono- and binary chalcogenide compounds [11-14]. Cadmium indium sulphide $\left(\mathrm{CdIn}_{2} \mathrm{~S}_{4}\right)$ belonging to ternary semiconductors of chalcogenide $\mathrm{AB}_{2} \mathrm{X}_{4}$ and being considered to have potential applications in optical devices, solar cells [15] and photocatalysts for $\mathrm{H}_{2}$ evolution, bacterial inactivation, and organic pollutant elimination [1618]. Considering the advantages of nanostructures over the bulk materials, attempts have been made to synthesize $\mathrm{CdIn}_{2} \mathrm{~S}_{4}$ with variety of nanostructures. Up to now, the nanostructural $\mathrm{CdIn}_{2} \mathrm{~S}_{4}$ has been synthesized by methods like hydrothermal $[15,19]$, microwave [20], and sol-gel [21] with template. In most cases, these techniques require high temperature or high pressure to obtain crystalline material. In 
addition, the removal of the templates requires additional processing steps that can be costly and wasteful. Thus, a highyield synthetic and template-free method for the $\operatorname{CdIn}_{2} S_{4}$ preparation can undoubtedly benefit the design of highperformance materials in catalytic applications. Recently, ultrasonic spray pyrolysis technique (USP) is particularly attractive. It is fast, inexpensive, vacuumless, and suitable for mass production [22-24]. In the previous work, we have demonstrated that the USP method is a common method to prepare multinary sulfide [25].

In present work, the $\mathrm{CdIn}_{2} \mathrm{~S}_{4}$ microspheres were synthesized using USP process. The effect of reaction conditions on the prepared $\mathrm{CdIn}_{2} \mathrm{~S}_{4}$ was studied. The obtained microspherical $\mathrm{CdIn}_{2} \mathrm{~S}_{4}$ was used as photocatalyst to oxidize azo dyes in aqueous solution.

\section{Experimental Section}

2.1. Catalysts Preparation. All of the reagents were of analytical grade and used without further purification. The $\mathrm{CdIn}_{2} \mathrm{~S}_{4}$ photocatalyst was prepared by a USP method. In a typical synthesis, $0.532 \mathrm{~g} \mathrm{Cd}(\mathrm{AC})_{2} \cdot 2\left(\mathrm{H}_{2} \mathrm{O}\right), 1.2 \mathrm{~g} \mathrm{InCl}_{3}\left(\mathrm{H}_{2} \mathrm{O}\right)_{4}$, and $0.76 \mathrm{~g} \mathrm{CH}_{4} \mathrm{~N}_{2} \mathrm{~S}$ were added into $150 \mathrm{~mL}$ water under magnetic stirring to form a transparent solution. The solution was nebulized at $1.7 \mathrm{MHz} \pm 10 \%$ (YUYUE402AI, Shanghai) and then carried by air with a flow rate $10 \mathrm{~L} / \mathrm{min}$ through a quartz tube surrounded by a furnace thermostated at $500 \sim 700^{\circ} \mathrm{C}$. The quartz reaction tube with the diameter of $3.5 \mathrm{~cm}$ was $1 \mathrm{~m}$ long. The products were collected in a percolator with distilled water, separated by centrifugation, and washed thoroughly with ethanol and distilled water. The product was finally dried in an oven at $60^{\circ} \mathrm{C}$ for overnight.

2.2. Characterization. Powder X-ray diffraction (XRD) patterns were collected in $\theta-\theta$ mode using a Bruker D8 Advance $\mathrm{X}$-ray diffractometer $(\mathrm{Cu} \mathrm{K} \alpha 1$ irradiation, $\lambda=1.5406 \AA)$. The morphology of the sample was investigated by field emission scanning electron microscopy (FSEM) (JSM-6700F). Transmission electron microscopy (TEM) was recorded on a FEI Tecnai 20 microscope. Carbon-coated copper grid was used as the sample holder. The sample was suspended in ethanol solution, followed by sonication for $30 \mathrm{~min}$ in the ultrasonic bath. Drops of the suspensions were applied on a copper grid coated with carbon. Nitrogen sorption experiments were carried out at $77 \mathrm{~K}$ by using Micromeritics ASAP 2020 equipment. All the samples were degassed at $140^{\circ} \mathrm{C}$ and $10^{-6}$ torr for $6 \mathrm{~h}$ prior to the measurement. The UV-visible diffuse reflectance spectra were performed on a Varian Cary 500 spectrometer with an integrating sphere attachment ranging from $200 \mathrm{~nm}$ to $800 \mathrm{~nm}$. $\mathrm{BaSO}_{4}$ was used as a reference sample in these measurements.

2.3. Evaluation of Photocatalytic Activity. The photocatalytic activities of the samples were evaluated by the decomposition of methyl orange (MO) a typical azo dye in aqueous solution. Catalyst $(0.05 \mathrm{~g})$ was suspended in a $100 \mathrm{~mL}$ Pyrex glass vessel containing $\mathrm{MO}$ with a concentration of $25 \mathrm{ppm}$. The visible light source was a $300 \mathrm{~W}$ halogen lamp (Philips Electronics)

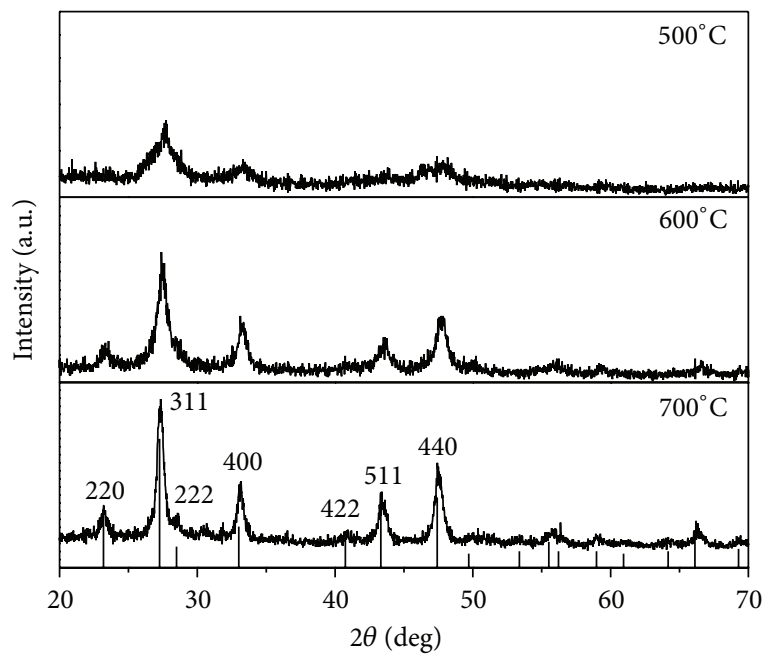

FIGURE 1: XRD patterns of $\mathrm{CdIn}_{2} \mathrm{~S}_{4}$ prepared at different temperatures.

positioned beside a cylindrical reaction vessel with a flat side. The system was water-cooled to maintain the temperature. A $400 \mathrm{~nm}$ cutoff filter was placed in front of the vessel to ensure irradiation by visible light. The suspension was stirred in darkness for $1 \mathrm{~h}$ to achieve adsorption equilibrium and the reactor was irradiated to induce photocatalyzed decomposition reactions. At given irradiation time intervals, $3 \mathrm{~mL}$ of the reaction suspension was collected and centrifuged to remove the catalyst. The degraded solution was analyzed using a Varian Cary 50 Scan UV-Vis spectrophotometer.

\section{Results and Discussion}

3.1. Crystal Structure. The X-ray diffraction (XRD) patterns of the resultant products synthesized from USP process at different temperature are shown in Figure 1. The XRD patterns of the sample prepared at $700^{\circ} \mathrm{C}$ can be indexed to cubic CdIn $\mathrm{S}_{4}$ well consistent with the reported data (JCPDS number $27-60$, space group: $\mathrm{Fd}-3 \mathrm{~m}$ ). The peaks at $2 \theta$ values of $23.18,27.25,28.48,33.00,40.74,43.31$, and 47.40 match well with the (220), (311), (222), (400), (422), (511), and (440) crystal planes of $\mathrm{CdIn}_{2} \mathrm{~S}_{4}$, respectively. There is no any trace of impurity phase such as CdS, $\mathrm{In}_{2} \mathrm{~S}_{3}$ under the instrument resolution, indicating the high purity of the sample. Furthermore, the intensity of the peaks according to $\mathrm{CdIn}_{2} \mathrm{~S}_{4}$ is affected by the preparation temperature. The XRD pattern for the sample prepared at $500^{\circ} \mathrm{C}$ shows broad noisy peaks means the semi crystalline nature of the sample. The intensity of peaks is increasing with the increasing of temperature. This suggests that the crystalline of $\mathrm{CdIn}_{2} \mathrm{~S}_{4}$ increases with the increase of temperature. The calculated average crystal sizes of the samples prepared at 500,600 , and $700^{\circ} \mathrm{C}$ using the Scherrer equation are $5.4,8.4$, and $14.2 \mathrm{~nm}$, respectively.

3.2. Morphology. Figure 2 depicts the FSEM images of prepared samples. Figure 2(a) is the low-magnification image of 


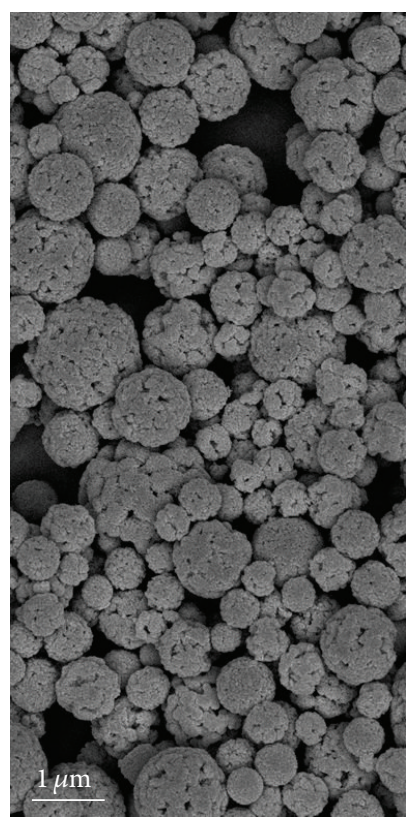

(a)

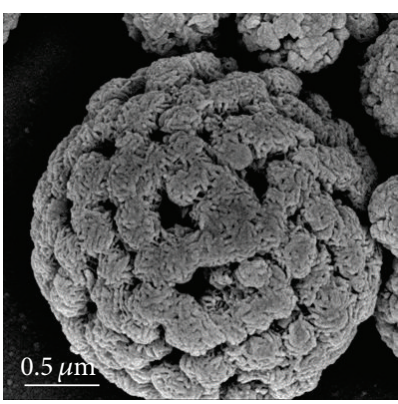

(b)

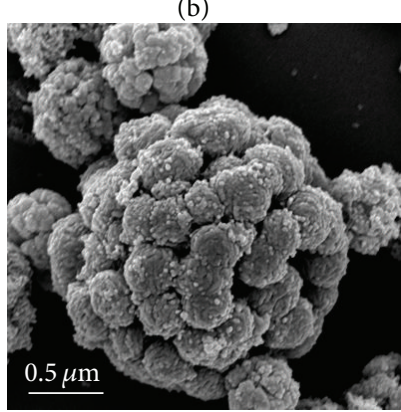

(c)
FIGURE 2: The FSEM images of $\mathrm{CdIn}_{2} \mathrm{~S}_{4}$ prepared by ultrasonic spray pyrolysis. (a) and (b) $500^{\circ} \mathrm{C}$, (c) $700^{\circ} \mathrm{C}$.

the sample prepared at $500^{\circ} \mathrm{C}$ which indicates that the asprepared samples consist entirely of spheres with a range of $100 \mathrm{~nm}$ to $1.5 \mu \mathrm{m}$. The ultrasonic nebulizer during the preparation is the key to form the spherical morphology. The aerosol produced from nebulizer consisted of numerous small liquid droplets which contained the precursor. These droplets would serve as microreactors and yield one spherical particle per droplet. The size of droplet and concentration of precursor determines the product dimension [26]. When these droplets are carried into the tubular reactor with air, the water in the droplet is heated and evaporating. At the same time, the thiourea in the droplet would decompose quickly and release $\mathrm{H}_{2} \mathrm{~S}$ which would react with the metal precursor quickly and generate submicrospherical CdIn $\mathrm{S}_{4}$. The excess $\mathrm{H}_{2} \mathrm{~S}$ from thiourea will be absorbed by the water in the percolator which will not be released out of system. Figure 2(b) is the magnified surface morphologies of samples prepared at $500^{\circ} \mathrm{C}$ which shows the porous structure of sample. The porous structure will not be destroyed even prepared at high temperature of $700^{\circ} \mathrm{C}$ (see Figure $2(\mathrm{c})$ ). The result also shows that the sample prepared at $500^{\circ} \mathrm{C}$ has a crude surface compared with the sample prepared at $700^{\circ} \mathrm{C}$. This can be due to the larger catalyst particles for the sample prepared under higher temperature.

The TEM image of $\mathrm{CdIn}_{2} \mathrm{~S}_{4}$ sphere in Figure 3 confirms that the prepared spheres are composed of small nanoparticles and have porous structure. The porous structure will endow the $\mathrm{CdIn} \mathrm{In}_{4}$ with more active points and larger lightharvesting ability which will benefit its photocatalytic performance. The composition of $\mathrm{CdIn}_{2} \mathrm{~S}_{4}$ sphere was determined by energy dispersive X-ray spectroscopy (EDX) in the " $\mathrm{A}$ " position of Figure 3. The results of EDX analysis (Figure 4) imply that the as-prepared samples contain In, Cd, S, and a

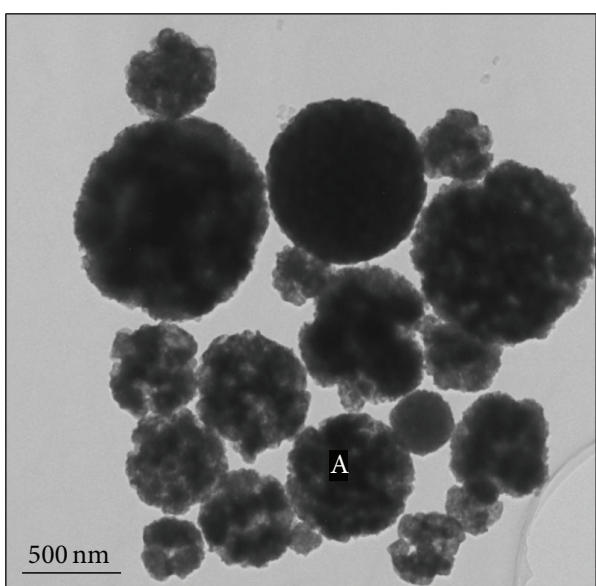

Figure 3: The TEM images of $\mathrm{CdIn}_{2} \mathrm{~S}_{4}$ prepared at $500^{\circ} \mathrm{C}$.

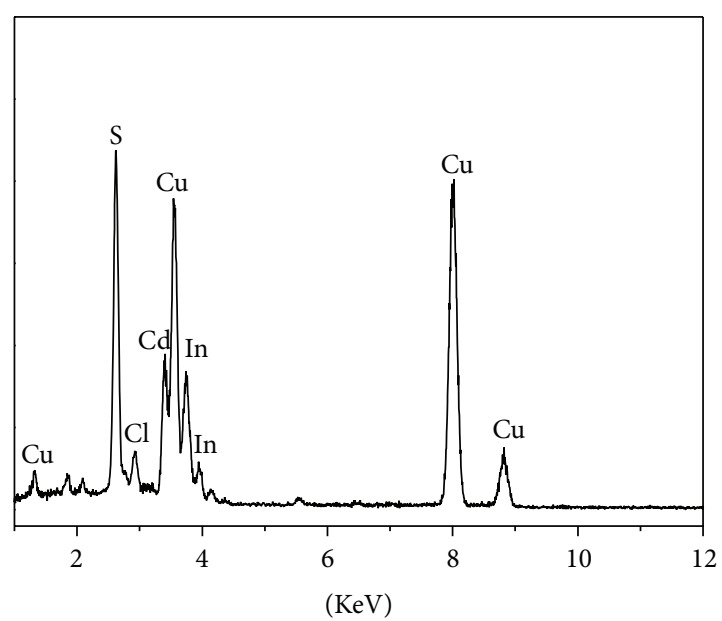

FIgURE 4: Energy-dispersive X-ray analysis spectra of $\mathrm{CdIn}_{2} \mathrm{~S}_{4}$ prepared at $500^{\circ} \mathrm{C}$.

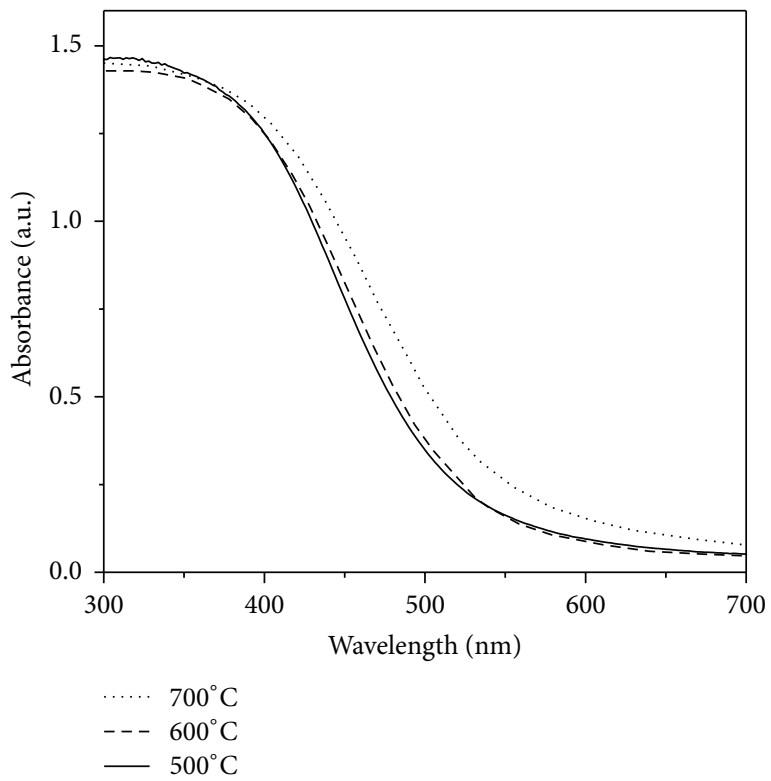

FIGURE 5: Diffuse reflectance UV-Vis spectra of $\mathrm{CdIn}_{2} \mathrm{~S}_{4}$ prepared at different temperature. 


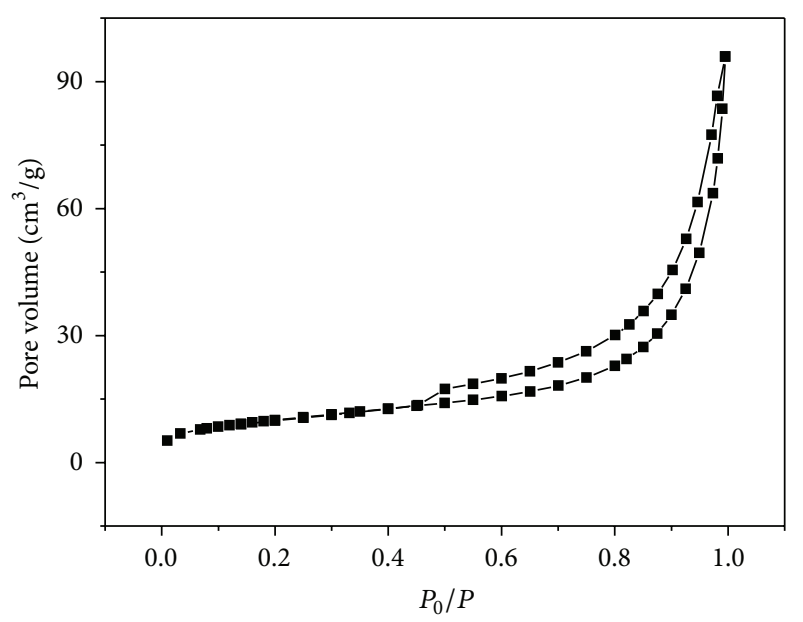

(a)

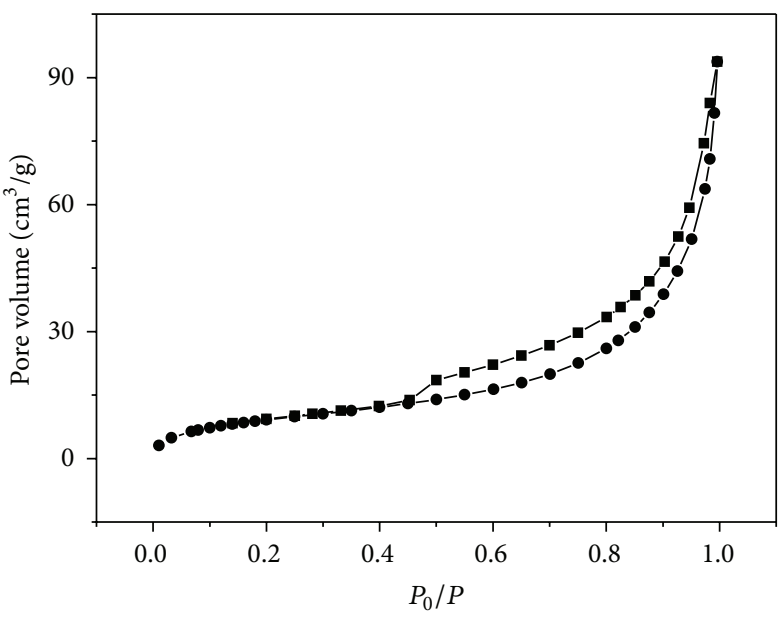

(b)

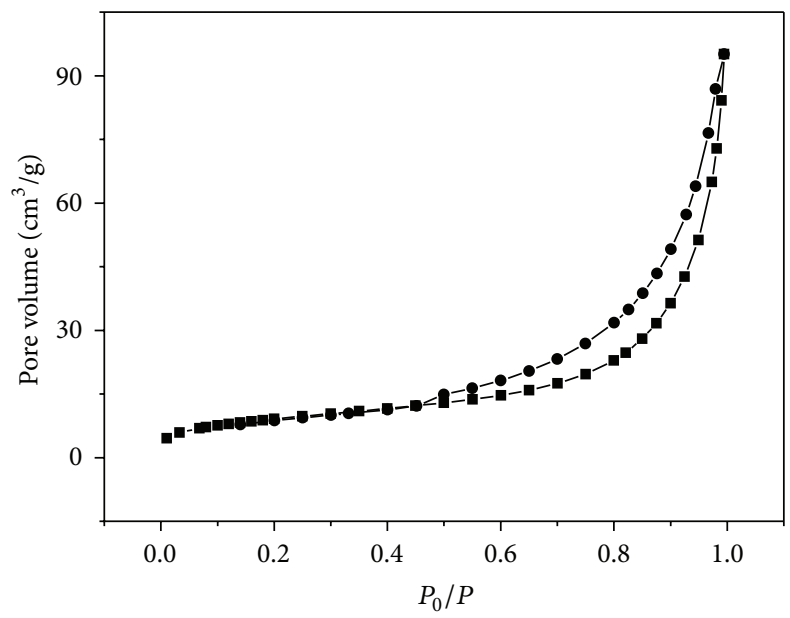

(c)

Figure 6: $\mathrm{N}_{2}$ adsorption-desorption isothermal curves of $\mathrm{CdIn}_{2} \mathrm{~S}_{4}$ prepared at different temperatures (a) $500^{\circ} \mathrm{C}$, (b) $600^{\circ} \mathrm{C}$, and (c) $700^{\circ} \mathrm{C}$.

small amount of $\mathrm{Cl}$ element. The ratio of In to $\mathrm{Cd}$ in the microspheres is 1.95 which is very close to the atom ratio in $\mathrm{CdIn}_{2} \mathrm{~S}_{4}$. The small amount $\mathrm{Cl}$ element is from the precursor of $\mathrm{InCl}_{3}\left(\mathrm{H}_{2} \mathrm{O}\right)_{4}$ which is not completely removed during the washing of product.

3.3. Optical Properties. Figure 5 shows the light absorption properties of prepared samples. All the samples show remarkable absorption in the visible light region. Besides, the basic adsorption edge of the $\mathrm{CdIn}_{2} \mathrm{~S}_{4}$ is shifted to shorter wavelength with the decreasing of temperature in preparation. The absorption edges of $\mathrm{CdIn}_{2} \mathrm{~S}_{4}$ prepared at 500,600 , and $700^{\circ} \mathrm{C}$ are 522,528 , and $541 \mathrm{~nm}$ corresponding to a band gap of 2.38 , 2.35 , and $2.29 \mathrm{eV}$, respectively. The blue shifts of adsorption edge are due to the quantum confinement effect, which is attributed to the smaller crystal size of $\mathrm{CdIn}_{2} \mathrm{~S}_{4}$ prepared in low temperature.

3.4. Specific Surface Area and Pore Structure. Figure 6 shows the nitrogen adsorption-desorption isotherms of the CdIn $\mathrm{S}_{4}$ prepared at different temperature. All the samples show similar type-IV isotherms, which are representative of mesoporous solids. In addition, the surface area, pore size, and pore volume (see Table 1) have no significant difference for the samples prepared in the different temperature. This indicates that the mesoporous structures was not destroyed or did not shrink in the high temperature which is consistent with the result of SEM in Figure 2.

3.5. Photocatalytic Activity. Figure 7 shows the photocatalytic degradation of methyl orange (MO) on $\mathrm{CdIn}_{2} \mathrm{~S}_{4}$ microspheres with otherwise identical conditions under visiblelight irradiation $(\lambda>400 \mathrm{~nm})$ after the adsorption desorption equilibrium was reached. The control test (without catalyst) under visible light irradiation showed that the photolysis of $\mathrm{MO}$ was negligible. The dark control experiment with $\mathrm{CdIn}_{2} \mathrm{~S}_{4}$ prepared at $500^{\circ} \mathrm{C}$ alone reveals that the concentration of $\mathrm{MO}$ was also unchanged after 3 hours, which demonstrates that the adsorption/desorption equilibrium had been obtained after 1 hour in dark and the $\mathrm{CdIn}_{2} \mathrm{~S}_{4}$ microspheres would not react with $\mathrm{MO}$. The $\mathrm{MO}$ was 
TABLE 1: Crystalline and porous properties of $\mathrm{CdIn}_{2} \mathrm{~S}_{4}$ prepared at different temperatures.

\begin{tabular}{lcccc}
\hline Temperature $\left({ }^{\circ} \mathrm{C}\right)$ & $d^{\mathrm{a}}(\mathrm{nm})$ & Pore $\operatorname{size}^{\mathrm{b}}(\mathrm{nm})$ & Surface $\operatorname{area}^{\mathrm{c}}\left(\mathrm{m}^{2} \mathrm{~g}^{-1}\right)$ & Pore volume $^{\mathrm{d}}\left(\mathrm{cm}^{3} \mathrm{~g}^{-1}\right)$ \\
\hline 500 & 5.4 & 13.5 & 36.1 & 0.15 \\
600 & 8.4 & 13.5 & 34.5 & 0.15 \\
700 & 14.2 & 13.6 & 33.5 & 0.15 \\
\hline
\end{tabular}

${ }^{\mathrm{a}} d$ values of the samples estimated by Scherrer formula; ${ }^{\mathrm{b}} \mathrm{BJH}$ pore sizes determined from the nitrogen desorption branches; ${ }^{\mathrm{c}} \mathrm{BET}$ surface areas determined from the nitrogen adsorption and desorption isotherm measurement; ${ }^{\mathrm{d}}$ pore volumes is the $\mathrm{BJH}$ desorption cumulative pore volume of pores.

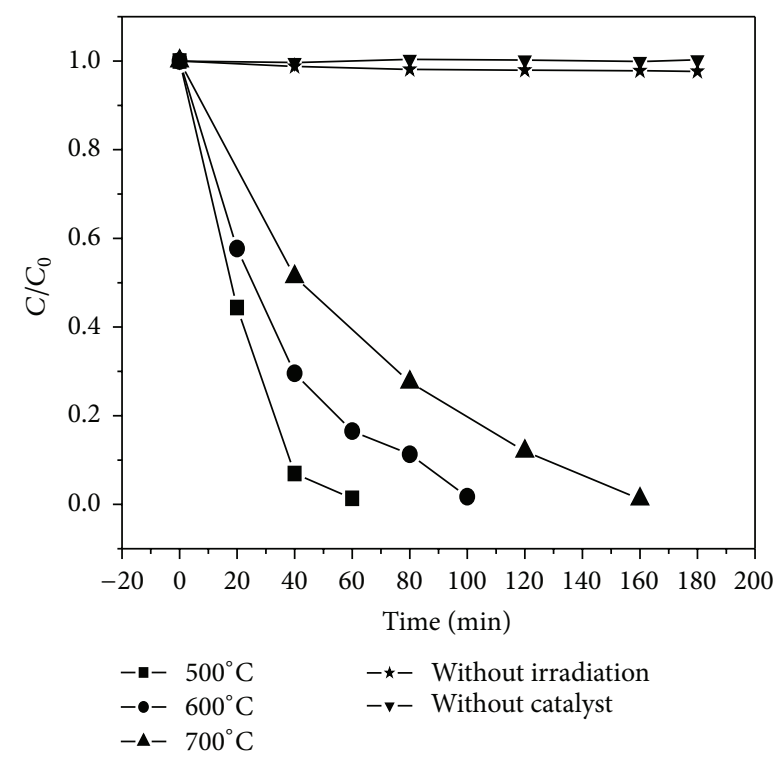

FIGURE 7: Photocatalytic activity of the $\mathrm{CdIn}_{2} \mathrm{~S}_{4}$ sphere samples.

degraded quickly in the presence of $\mathrm{CdIn}_{2} \mathrm{~S}_{4}$ under visible light irradiation and indicates the high photocatalytic activity of $\mathrm{CdIn}_{2} \mathrm{~S}_{4}$ microspheres. The test also shows that the activities of doped samples were greatly influenced by the prepared temperature. The complete degradation of methyl orange for samples prepared at 500,600 , and $700^{\circ} \mathrm{C}$ needs 60,100 , and $160 \mathrm{~min}$, respectively. Considering the similar surface area and pore structure among different samples, the higher photocatalytic activity for the sample prepared at $500^{\circ} \mathrm{C}$ can be due to the small crystal size which is of benefit to the separation of excited electron/hole pair during photocatalytic reaction.

\section{Conclusions}

The $\mathrm{CdIn}_{2} \mathrm{~S}_{4}$ have been synthesized by using ultrasonic spray pyrolysis process without using any template. The prepared samples have spherical morphology with mesoporous structure whose products can be generated continuously at a rate of several grams per hour. The prepared $\mathrm{CdIn}_{2} \mathrm{~S}_{4}$ exhibited excellent photocatalytic activity. We expect that these $\mathrm{CdIn}_{2} \mathrm{~S}_{4}$ spheres prepared with this method will have immense importance in other regions such as solar cells, LED, and optoelectronics.

\section{Conflict of Interests}

The authors declare that there is no conflict of interests regarding the publication of this paper.

\section{Acknowledgments}

This work was supported by the National Natural Science Foundation of China (21103095), the Excellent Young Scientific Research Talents in University of Fujian, China (JA12285), the Education and Scientific Project for the Young and Middle Aged Teachers of Fujian, China (JA13279), and Scientific Project of Putian Science and Technology Burea (2013S03(3)).

\section{References}

[1] C. Sahoo, A. K. Gupta, and A. Pal, "Photocatalytic degradation of Methyl Red dye in aqueous solutions under UV irradiation using $\mathrm{Ag}^{+}$doped $\mathrm{TiO}_{2}$," Desalination, vol. 181, no. 1-3, pp. 91100, 2005.

[2] C. Wang, A. Yediler, D. Lienert, Z. Wang, and A. Kettrup, "Toxicity evaluation of reactive dyestuffs, auxiliaries and selected effluents in textile finishing industry to luminescent bacteria Vibrio fischeri," Chemosphere, vol. 46, no. 2, pp. 339-344, 2002.

[3] A. A. Essawy, A. E.-H. Ali, and M. S. A. Abdel-Mottaleb, "Application of novel copolymer- $\mathrm{TiO}_{2}$ membranes for some textile dyes adsorptive removal from aqueous solution and photocatalytic decolorization," Journal of Hazardous Materials, vol. 157, no. 2-3, pp. 547-552, 2008.

[4] C. Wang, A. Yediler, D. Lienert, Z. Wang, and A. Kettrup, "Ozonation of an azo dye C.I. Remazol Black 5 and toxicological assessment of its oxidation products," Chemosphere, vol. 52, no. 7, pp. 1225-1232, 2003.

[5] K. T. Chung and S. E. J. Stevens, "Degradation azo dyes by environmental microorganisms and helminths," Environmental Toxicology and Chemistry, vol. 12, no. 11, pp. 2121-2132, 1993.

[6] A. Gottlieb, C. Shaw, A. Smith, A. Wheatley, and S. Forsythe, "The toxicity of textile reactive azo dyes after hydrolysis and decolourisation," Journal of Biotechnology, vol. 101, no. 1, pp. 4956, 2003.

[7] E. Razo-Flores, M. Luijten, B. Donlon, G. Lettinga, and J. Field, "Biodegradation of selected azo dyes under methanogenic conditions," Water Science and Technology, vol. 36, no. 6-7, pp. 65-72, 1997.

[8] R. Ganesh, G. D. Boardman, and D. Michelsen, "Fate of azo dyes in sludges," Water Research, vol. 28, no. 6, pp. 1367-1376, 1994.

[9] J. Huang, K. Ding, Y. Hou, X. Wang, and X. Fu, "Synthesis and photocatalytic activity of $\mathrm{Zn}_{2} \mathrm{GeO}_{4}$ nanorods for the degradation of organic pollutants in water," ChemSusChem, vol. 1, no. 12, pp. 1011-1019, 2008. 
[10] C. S. Turchi and D. F. Ollis, "Photocatalytic degradation of organic water contaminants: mechanisms involving hydroxyl radical attack," Journal of Catalysis, vol. 122, no. 1, pp. 178-192, 1990.

[11] Q. Guo, G. M. Ford, H. W. Hillhouse, and R. Agrawal, "Sulfide nanocrystal inks for dense $\mathrm{Cu}\left(\operatorname{In}_{1-x} \mathrm{Ga}_{x}\right)\left(S_{1-y} \mathrm{Se}_{y}\right)$, absorber films and their photovoltaic performance," Nano Letters, vol. 9 , no. 8, pp. 3060-3065, 2009.

[12] X. Zhang, Y. Du, Z. Zhou, and L. Guo, "A simplified method for synthesis of band-structure-controlled (Culn) ${ }_{x} \mathrm{Zn}_{2(1-x)} \mathrm{S}_{2}$ solid solution photocatalysts with high activity of photocatalytic $\mathrm{H}_{2}$ evolution under visible-light irradiation," International Journal of Hydrogen Energy, vol. 35, no. 8, pp. 3313-3321, 2010.

[13] I. Tsuji, Y. Shimodaira, H. Kato, H. Kobayashi, and A. Kudo, "Novel stannite-type complex sulfide photocatalysts $\mathrm{A}_{2}^{I}-\mathrm{Zn}$ $\mathrm{A}^{\mathrm{IV}}-\mathrm{S}_{4}\left(\mathrm{~A}^{I}=\mathrm{Cu}\right.$ and $\mathrm{Ag} ; \mathrm{A}^{\mathrm{IV}}=\mathrm{Sn}$ and $\left.\mathrm{Ge}\right)$ for hydrogen evolution under visible-light irradiation," Chemistry of Materials, vol. 22, no. 4, pp. 1402-1409, 2010.

[14] Y. Li, G. Chen, C. Zhou, and J. Sun, "A simple template-free synthesis of nanoporous $\mathrm{ZnS}-\mathrm{In}_{2} \mathrm{~S}_{3}-\mathrm{Ag}_{2} \mathrm{~S}$ solid solutions for highly efficient photocatalytic $\mathrm{H}_{2}$ evolution under visible light," Chemical Communications, no. 15, pp. 2020-2022, 2009.

[15] L. Fan and R. Guo, "Fabrication of novel CdIn $\mathrm{S}_{4}$ hollow spheres via a facile hydrothermal process," Journal of Physical Chemistry C, vol. 112, no. 29, pp. 10700-10706, 2008.

[16] B. B. Kale, J.-O. Baeg, S. M. Lee, H. Chang, S.-J. Moon, and C. W. Lee, "CdIn $\mathrm{S}_{4}$ nanotubes and "marigold" nanostructures: a visible-light photocatalyst," Advanced Functional Materials, vol. 16, no. 10, pp. 1349-1354, 2006.

[17] W. J. Wang, T. W. Ng, W. K. Ho et al., "CdIn $\mathrm{S}_{4}$ microsphere as an efficient visible-light-driven photocatalyst for bacterial inactivation: synthesis, characterizations and photocatalytic inactivation mechanisms," Applied Catalysis B: Environmental, vol. 129, pp. 482-490, 2013.

[18] A. Bhirud, N. Chaudhari, L. Nikam et al., "Surfactant tunable hierarchical nanostructures of $\mathrm{CdIn}_{2} \mathrm{~S}_{4}$ and their photohydrogen production under solar light," International Journal of Hydrogen Energy, vol. 36, no. 18, pp. 11628-11639, 2011.

[19] W. L. Jiang, X. H. Yin, F. Xin, Y. D. Bi, Y. Liu, and X. Li, "Preparation of $\mathrm{CdIn}_{2} \mathrm{~S}_{4}$ microspheres and application for photocatalytic reduction of carbon dioxide," Applied Surface Science, vol. 288, pp. 138-142, 2014.

[20] S. K. Apte, S. N. Garaje, R. D. Bolade et al., "Hierarchical nanostructures of CdIn $\mathrm{S}_{4}$ via hydrothermal and microwave methods: efficient solar-light-driven photocatalysts," Journal of Materials Chemistry, vol. 20, no. 29, pp. 6095-6102, 2010.

[21] J. M. Thornton and D. Raftery, "Hydrogen evolution by templated cadmium indate nanoparticles under natural sunlight illumination," International Journal of Hydrogen Energy, vol. 38, no. 19, pp. 7741-7749, 2013.

[22] Z. Ai, L. Zhang, and S. Lee, "Efficient visible light photocatalytic oxidation of $\mathrm{NO}$ on aerosol flow-synthesized nanocrystalline $\mathrm{InVO}_{4}$ hollow microspheres," Journal of Physical Chemistry C, vol. 114, no. 43, pp. 18594-18600, 2010.

[23] Y. Huang, Z. H. Ai, W. K. Ho, M. J. Chen, and S. C. Lee, "Ultrasonic spray pyrolysis synthesis of porous $\mathrm{Bi}_{2} \mathrm{WO}_{6}$ microspheres and their visible-light-iduced photocatalytic removal of NO," Journal of Physical Chemistry C, vol. 114, no. 14, pp. 6342-6349, 2010.

[24] S. E. Skrabalak and K. S. Suslick, "Porous $\mathrm{MoS}_{2}$ synthesized by ultrasonic spray pyrolysis," Journal of the American Chemical Society, vol. 127, no. 28, pp. 9990-9991, 2005.
[25] J. H. Huang, W. Cheuk, Y. F. Wu, F. S. C. Lee, and W. K. Ho, "Template-free synthesis of ternary sulfides submicrospheres as visible light photocatalysts by ultrasonic spray pyrolysis," Catalysis Science \& Technology, vol. 2, pp. 1825-1827, 2012.

[26] J. Zhang, A. Elsanousi, J. Lin et al., "Aerosol-assisted selfassembly of aluminum borate $\left(\mathrm{Al}_{18} \mathrm{~B}_{4} \mathrm{O}_{33}\right)$ nanowires into three dimensional hollow spherical architectures," Crystal Growth and Design, vol. 7, no. 12, pp. 2764-2767, 2007. 


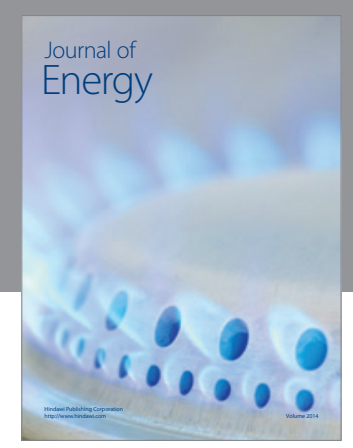

Journal of

Industrial Engineering
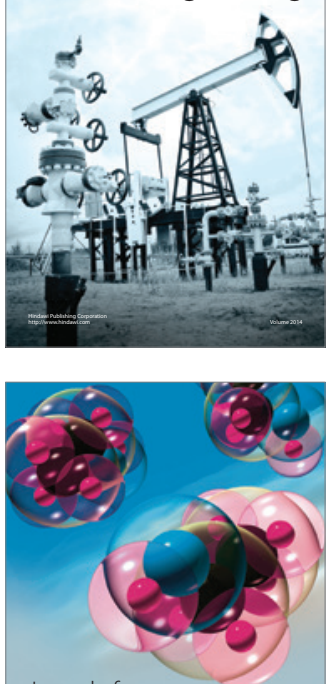

Fuels
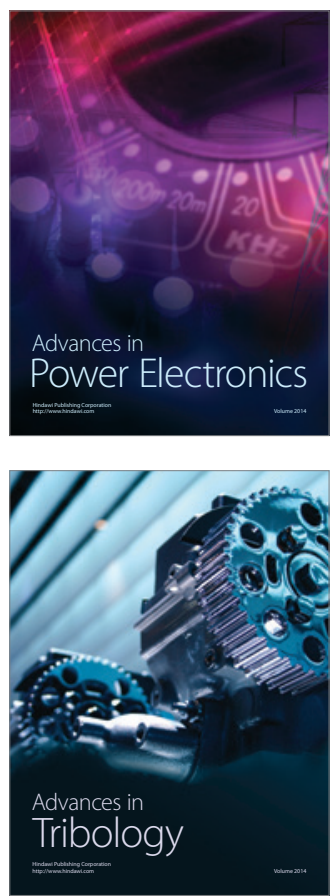

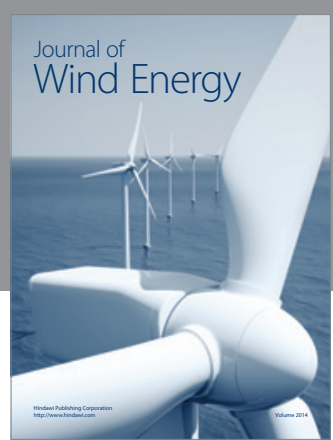

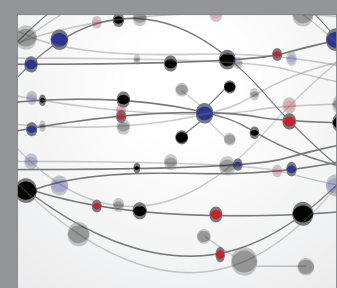

The Scientific World Journal

Submit your manuscripts at http://www.hindawi.com

Journal of

Structures
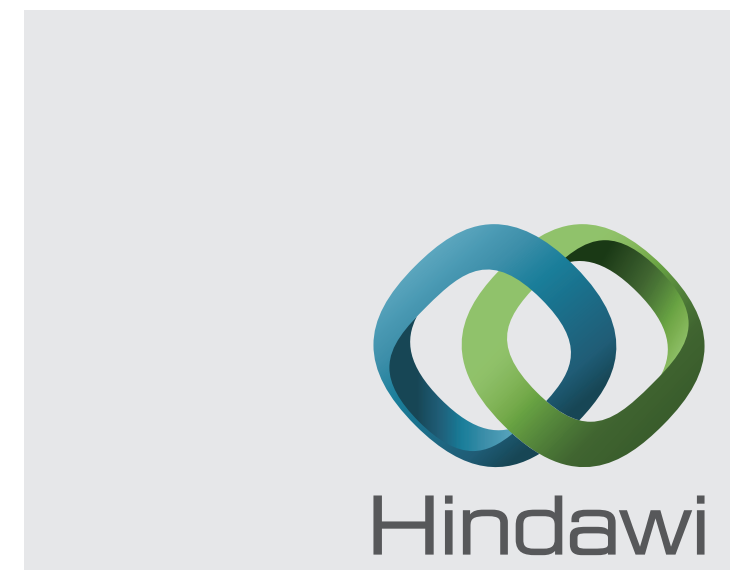

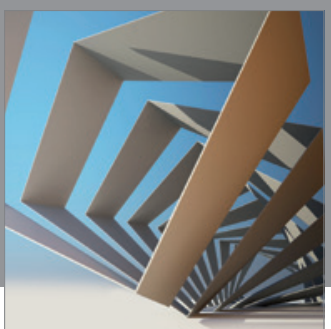

Rotating

Machinery
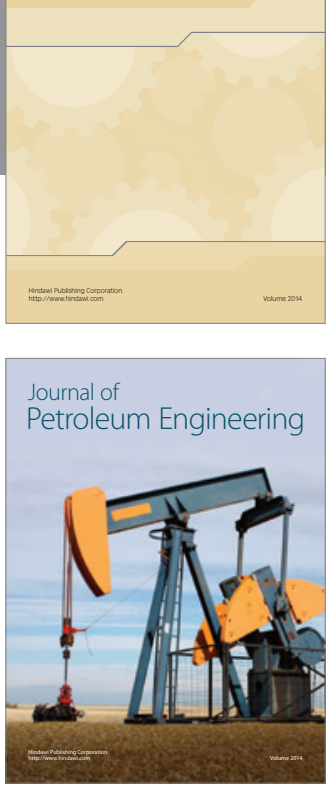

Journal of

Solar Energy
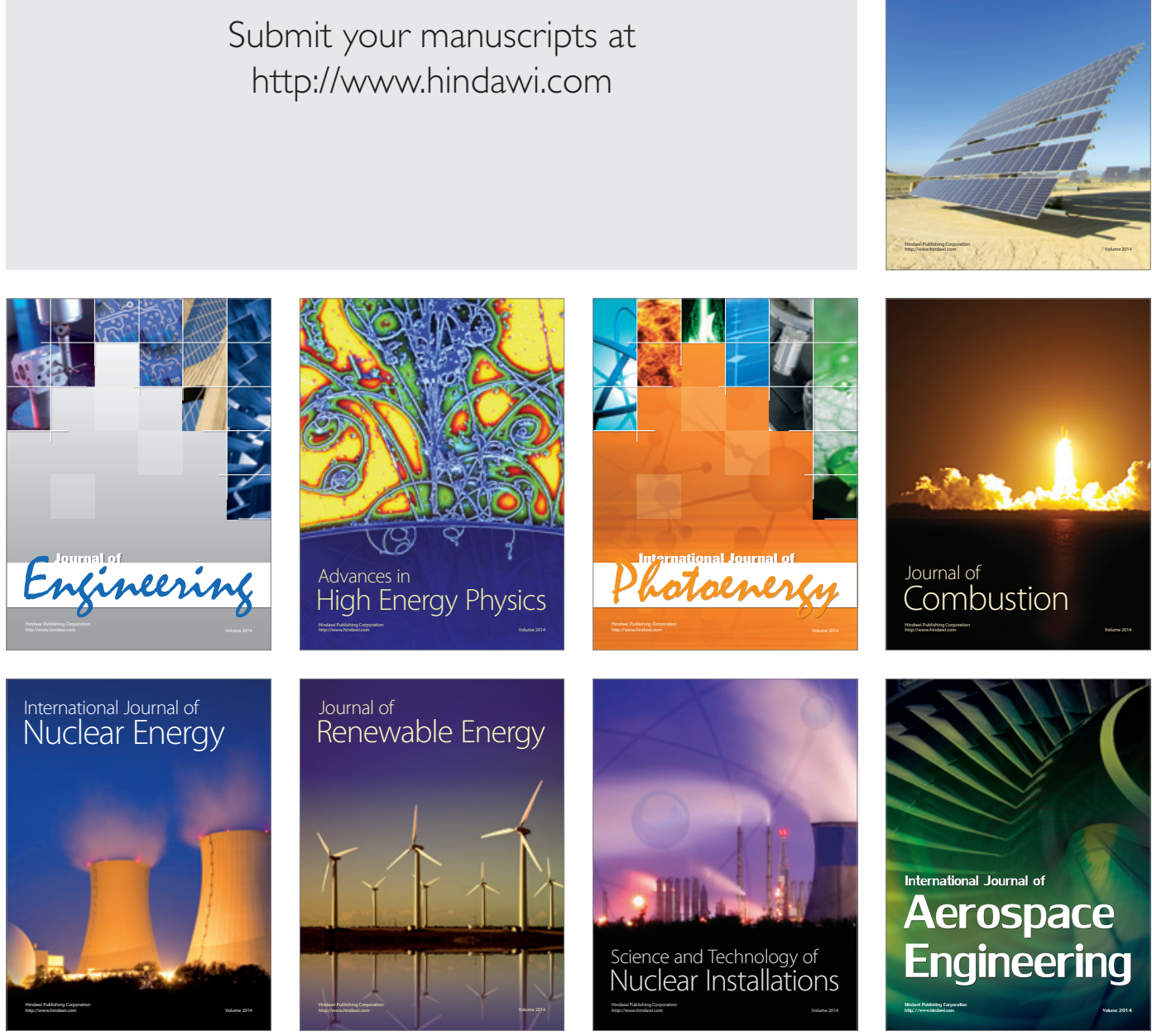